\title{
Innovative technique for the study of pneumoperitoneum in the evaluation of ab- dominal pain after chemical irritation with zymozan ${ }^{1}$
}

\author{
Técnica original para o estudo da influência do pneumoperitônio na avaliação da \\ intensidade da dor abdominal após irritação química com zimozan
}

\author{
Eduardo Crema', Bruna Ferrante Silva ${ }^{\mathrm{II}}$, Pauliana Lamounier e Silva ${ }^{\mathrm{III}}$, Virmondes Rodrigues Júnior ${ }^{\mathrm{IV}}$, Fernando Cunha ${ }^{\mathrm{V}}$ \\ ${ }^{\text {I }}$ PhD, Full Professor, Department of Digestive Surgery, Federal University of Triângulo Mineiro (UFTM), Uberaba - MG, Brazil. \\ ${ }^{\text {II }}$ MD, Postgraduate Program of Surgery, UFTM, Uberaba - MG, Brazil. \\ III Scientific Initiation Students, UFTM, Uberaba - MG, Brazil. \\ Iv Full Professor, Imunology, UFTM, Uberaba - MG, Brazil. \\ ${ }^{v}$ Full Professor, Pharmacology, UFTM, Uberaba - MG, Brazil.
}

\begin{abstract}
Purpose: To assess the influence of pneumoperitoneum in mice submitted to peritoneal irritation provoked by the biological agent Saccharomyces cerevisae, by counting the number of abdominal contractions elicited. Methods: To study the effects of pneumoperitoneum analgesic action, 60 mice were divided into two groups: the experimental group, subjected to pneumoperitoneum; and the control group, without pneumoperitoneum. The both groups received intraperitoneal injection of zymosan at a dose of $1 \mathrm{mg} / 0,2 \mathrm{ml} / \mathrm{mouse}$. Results: The sum of the number of abdominal contractions of the experimental group (with pneumoperitoneum) was significantly lower than that of the control group (without pneumoperitoneum). In the experimental group, a lower number of contractions occurred in each min compared to the control. Conclusion: The observation of the analgesic effect of pneumoperitoneum using CO2 in mice submitted to peritoneal irritation by zymosan was verified.
\end{abstract}

Key words: Laparoscopy. Zymosan. Pneumoperitoneum, Artificial. Abdominal Pain. Mice.

\section{RESUMO}

Objetivo: Avaliar a influência do pneumoperitônio em animais submetidos à irritação peritoneal provocada pelo agente biológico Saccharomyces cerevisae mediante a contagem do número de contrações abdominais. Métodos: Para o estudo do efeito da ação analgésica do pneumoperitônio os 60 camundongos foram divididos em dois grupos, grupo experimento (com pneumoperitôneo) e controle (sem pneumoperitôneo). Os dois grupos receberam injeção intraperitoneal de zimosan na dose de $1 \mathrm{mg} / 0,2 \mathrm{ml} /$ camundongo. Resultados: O somatório do número de contrações abdominais do grupo experimento (com pneumoperitôneo) foi significativamente menor que no grupo controle (sem pneumoperitôneo). O número médio de contrações no grupo controle foi significativamente maior quando comparado com o grupo experimento. Conclusão: Observou-se efeito analgésico do pneumoperitônio com $\mathrm{CO} 2$ em animais submetidos à irritação peritoneal pelo zimosan.

Descritores: Laparoscopia. Zimosan, Pneumoperitônio Artificial. Dor Abdominal. Camundongos.

1. Research performed at Experimental Laboratory of Surgery Techniques, Department of Surgery, Federal University of Triângulo Mineiro (UFTM), Uberaba - MG, Brazil.

\section{Introduction}

Currently, laparoscopic procedures have gained importance due to their advantages in relation to open surgery. Among these advantages, diminished postoperative pain, a reduction in respiratory complications, reduced hospital admittance and an early return to normal activities can be cited ${ }^{1,2,3}$.

To perform laparoscopic surgery, separation of the abdominal wall from the abdominal viscera is required and the most commonly used technique is pneumoperitoneum, which is realized with $\mathrm{CO} 2$ insufflation in the intraperitoneal cavity ${ }^{1,2,4}$.

When laparoscopy was first performed, pneumoperitoneum was treated as prejudicial, since it diminished venous return, causing $\mathrm{CO} 2$ retention, Later, studies demonstrated that pneumoperitoneum maybe responsible for the enormous benefits of laparoscopic surgery by liberating inflammatory cytokines (IL-4 and IL-10), which are potent analgesics ${ }^{1,5,6}$.

Among patients that require analgesia, low-pressure pneumoperitoneum reduces the demand for anesthetic agents. The analgesic effect of pneumoperitoneum is maintained for 35 postoperative days, further contributing to better quality of life in these patients ${ }^{3}$.

The beneficial effects of insufflation have been related to mastocyte degranulation, responsible for the liberation of vasoactive substances (histamine, adrenalin) and cytokines (IL-4 and IL-10), denominated as antiinflammatory, which have been shown to limit the inflammatory response to pain, inhibiting the production of hyperallergic cytokines and prostaglandins ${ }^{3}$. 
Even so, no consensus exists regarding the benefits of its use, since it induces adverse reactions in cardiovascular and pulmonary function, despite the fact the hemodynamic repercussions have been reduced with the use of low-pressure pneumoperitoneum and are not statistically significant ${ }^{7}$.

To study inflammatory and pain reaction, the use of peritoneal irritants, such as thioglycollate, sephadex and zymosan, have been used by several authors ${ }^{8,9}$.

This work aimed to assess the influence of pneumoperitoneum in mice submitted to peritoneal irritation provoked by the biological agent saccharomyces cerevisae, by counting the number of abdominal contractions elicited.

\section{Methods}

Seventy male BALB/c mice were selected, aged 3035 days and weighing between $20-25 \mathrm{~g}$, reared in the animal center of the Triangulo Mineiro Federal University. All the surgical procedures followed the criteria, technical norms and international laws regarding research on animals determined by the Ethics Committee of the Brazilian College of Animal Experimentation (Comitê de Ética do Colégio Brasileiro de Experimentação Animal, COBEA), with the approval of the Ethics Advisory Committee of the same institute (Brazilian Association for Animal Studies; Associação Brasileira para Estudos Animais).

To study the effects of pneumoperitoneum analgesic action, 60 mice were divided into two groups: the experimental group, subjected to pneumoperitoneum; and the control group, without pneumoperitoneum.

All the procedures were realized under inhalatory anesthetic, using diethyl ether.

The technique use to perform the pneumoperitoneum included punction of the median line of the anterior abdomen wall with a no. 18 (18-G) angiocath. Insufflation with $\mathrm{CO} 2$ was maintained by a digital insufflator (Karl Storz Co., Culver City, CA, USA), at a constant pressure of $5 \mathrm{mmHg}$ for $20 \mathrm{~min}$. A system was developed with a disposable 3-via tap and two latex extensions, permitting the maintenance of pneumoperitoneum in four mice simultaneously. The mice were anesthetized by nasal cone lined with cotton-wool soaked in ether. After 20 min, insufflation was interrupted and the injected $\mathrm{CO} 2$ was removed from the abdominal cavity by catheter with auxilliary digital compression and a change in mouse body position.

Aimed at assessing the analgesic effect of pneumoperitoneum, chemical irritation of abdominal cavity was realized by the biological agent saccharomyces cerevisae (zymosan), at a dose of $1 \mathrm{mg} / 0.2 \mathrm{ml} /$ mouse, prepared immediately prior to the experiment. The introduction of zymosan was realized along the median line of the anterior abdomen wall with a $1 \mathrm{ml}$ syringe attached to a needle.

The experimental group $(n=30)$ was divided in two subgroups of 15 mice each, which received intraperitoneal injection of zymosan 1 and 2 hours, respectively, after the end of pneumoperitoneum. The control group was also divided into two subgroups of 15 mice each, which received peritoneal irritation by the same technique and dose 1 and 2 hours after only being anesthetized.
After the zymosan injection, one mouse from the experimental group and one from the control group were placed in individual glass bell jars. For a period of $10 \mathrm{~min}$, the number of contractions was observed min by min, which were standardized as the extension of the four paws and a clear persistent contraction of the abdomen. The contractions were quantified by an individual counter for each mouse. For each min, the number of contractions was registered in an individual file and totaled after $10 \mathrm{~min}$.

Pain evaluation was quantified by the number of abdominal contractions obtained for each group, such that these numbers were compared inter and intragroup for each min and later submitted to statistical analysis.

\section{Statistical analysis}

The variable of interest, number of abdominal contractions, was initially submitted to the Kolmogorov-Smirnov normality test followed by Bartlett's test of homogeneity of variances. Intergroup comparisons for each min of observation were realized by the Mann-Whitney test and, intragroup comparisons between min were realized by Friedmann's test, followed by the Tukey test. The total number of contractions in the first 10 min was also considered, with comparative analysis realized by the Student $t$ test.

\section{Results}

All the mice submitted to the experiment presented good evolution.

As shown in Figure 1, the sum of the number of abdominal contractions of the experimental group $(1$ and $2 \mathrm{~h}$, with pneumoperitoneum) was significantly lower (11.47) than that of the control group $(22.93 ; 1$ and $2 \mathrm{~h}$, without pneumoperitoneum).

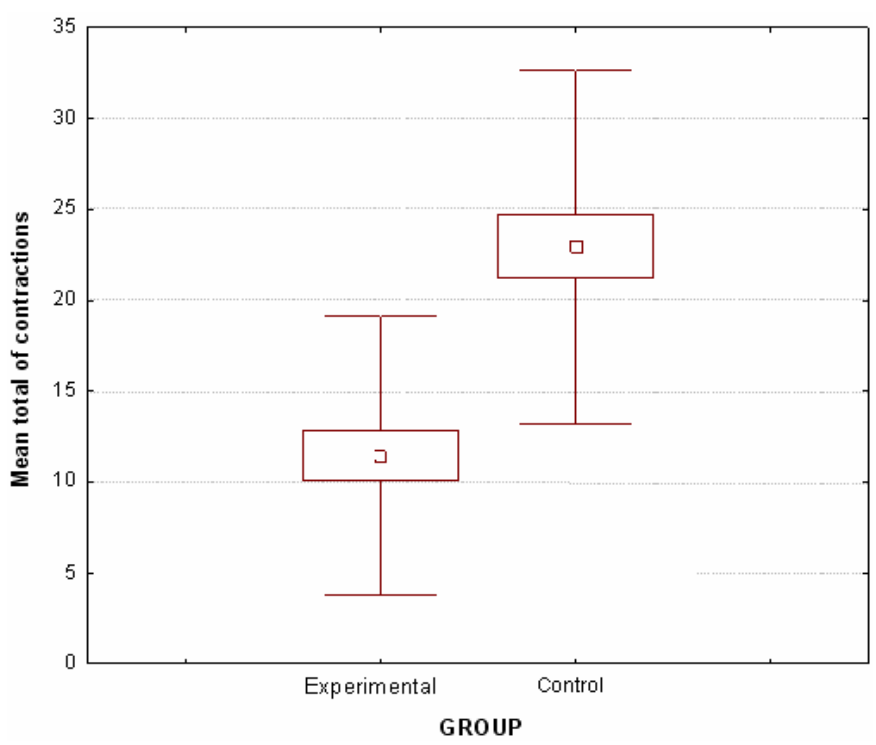

FIGURE 1 - The mean total of abdominal contractions in the groups studied 
Intragroup comparative analysis of the number of contractions after 1 and $2 \mathrm{~h}$ demonstrated that no significant difference occurred when comparing the experimental or control groups (Figure 2).

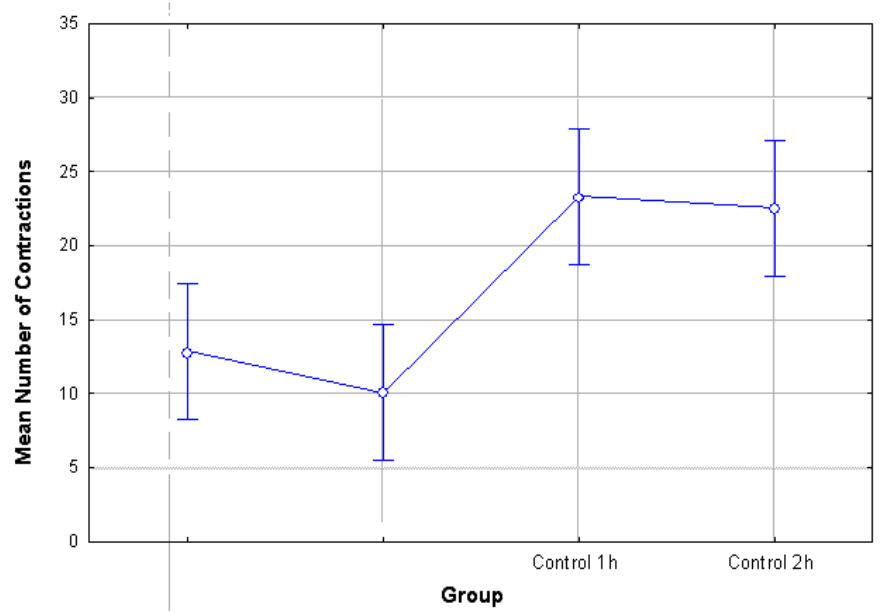

FIGURE 2 - The mean number of contractions at 1 and $2 \mathrm{~h}$ in the groups studied

Observation revealed that an increase in the number of abdominal contractions occurred up to $3 \mathrm{~min}$ in both groups, after which a tendency to decrease occurred up to $10 \mathrm{~min}$. In the experimental group, a lower number of contractions occurred in each min compared to the control. This statistical comparison was significant at all times, from 1 to $10 \mathrm{~min}$.

Observation showed that the mean number of contractions after 1 (22.33) and $2 \mathrm{~h}$ (22.53) in the control group was significantly greater compared to the experimental group (1h, 12.87; 2h, 10.06; Figure 2).

The min by min statistical analysis regarding the number of contractions demonstrated that after $2 \mathrm{~min}$, the number of contractions in mice without pneumoperitoneum was statistically greater at all times up to $10 \mathrm{~min}$ (Figure 3).

In both groups, an increase in the number of abdominal contractions occurred up to 3 min, after which a tendency to decrease occurred up to $10 \mathrm{~min}$ (Figure 3 ).

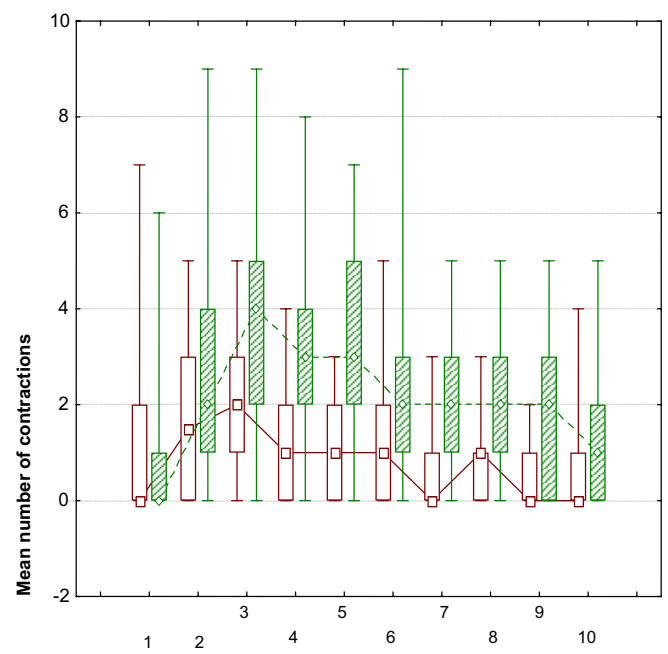

$\rightarrow-$ Experimenta

FIGURE 3 - Number of contractions minute by minute in the groups studied

\section{Discussion}

The majority of laparoscopic procedures performed involve pneumoperitoneum. When laparoscopy was first performed, the maintenance of positive intraabdominal pressure throughout the laparoscopic procedure was considered nonphysiological and associated with adverse metabolic, immunological, hemodynamic and oncological effects ${ }^{3,4}$.

Several clinical papers have shown the benefits of laparoscopic surgery in relation to the open surgery option ${ }^{2,6}$, most likely resulting from the liberation of cytokines IL-4, IL10 and IL-13 ${ }^{1,2}$.

As has been shown in large randomized studies, lowpressure pneumoperitoneum $(7 \mathrm{mmHg})$ leads to diminished pain and a $20 \%$ reduction in the number of patients requiring analgesia in the short-term postoperative period, when compared to individuals submitted to standard pneumoperitoneum pressure of $12 \mathrm{mmHg}^{10,11}$.

Given that pneumoperitoneum is a crucial element of laparoscopy, guidelines were established in order to reduce its adverse effects, such as a preoperative evaluation of the presence of cardiac, pulmonary, hepatic, renal and vascular comorbidities. Continuous monitorization of pressure levels so that they remain as low as possible, sufficient to achieve good exposure of the surgical field. The use of $2-5 \mathrm{~mm}$ trocars, rather than $5-10 \mathrm{~mm}$, was also established, contributing to diminished postoperative pain.

Certain peritoneal irritants have been used to study pain mechanisms, such as acetic acid and zymosan, which, minutes after injection into the abdominal cavity, provoke motor manifestations of abdominal contraction and limb extension; manifestations that can be easily quantified by a researcher and translate the abdominal pain felt by experimental animals ${ }^{12}$.

In an attempt to assess the real analgesic effect of pneumoperitoneum in animal experimentation, this study used a product that provokes peritoneal irritation (zymosan), as proven in cytokine/pain study protocols ${ }^{3,13,14}$.

Observation revealed that mice that were submitted to pneumoperitoneum presented a significantly lower mean number (11.47) of abdominal contractions (pain) than control group mice (22.93) after peritoneal irritation with zymosan (Figure 1).

Upon analyzing the moments 1 and $2 \mathrm{~h}$ after the realization of pneumoperitoneum prior to peritoneal irritation by zymosan, observation also showed that the mean number of contractions was statistically lower compared to the control group (without pneumoperitoneum). However, intragroup comparison of the pneumoperitoneum group at 1 and $2 \mathrm{~h}$ revealed no statistically significant difference in contractions (Figure 2), demonstrating the lasting effect of the analgesic action of pneumoperitoneum, probably resulting from the liberation of antiinflammatory substances (cytokines IL-4 and IL-10), as previously observed in a study on patients submitted to laparoscopic cholecystectomy ${ }^{1}$.

In all the mice studied, observation showed that peritoneal irritation was immediate, given that the onset of abdominal contractions occurred within the first min, increased up to 3 min, after which a tendency of decreased contractions occurred 
up to the end of 10 min studied; thus proving that the method is simple, cheap and easy to execute in the study of abdominal pain using peritoneal irritants. Similar observations were verified in a study by Vale et $a l^{15}$.

At all times, from the first min onward, the analgesic effect of pneumoperitoneum was observed in virtue of the significantly lower mean number of contractions in the experimental group subjected to pneumoperitoneum.

\section{Conclusion}

Observation of the analgesic effect of pneumoperitoneum using $\mathrm{CO} 2$ in mice submitted to peritoneal irritation by zymosan was verified.

\section{References}

1- Crema E, Werneck AM, Cruvinel LAF, Crema MD, Rodrigues Jr V, Silva AA. Analyse des Cytokines pro-inflammatoires (IL1 et TNF-alpha) et anti inflammatoires (IL-4 et IL-10) chez les patients soumis a la cholécystectomie ouvert et coelioscopique. Eur J Coelio Surg. 2003,48:63-7.

2- Crema E, Rodrigues Jr V, Silva AA, Oliveira CB, Pereira GA, Gomes RAS, Hial V. Comparative study of Surgical stress determined by hormone and cytokine plasma levels in open and laparoscopic cholecystectomy. I H P B A, Budapest European Congress, 1999, p. 37-40.

3- Mouton WG, Bessel JR, Otten KT. Pain after laparoscopy. Surg Endosc. 1999;13(5):445-8.

4- Neudecker J, Sauerland S, Neugebauer E, Bergamaschi R, Bonjer HJ, Cuschieri A, Fuchs KH, Jacobi Ch, Jansen FW, Koivusalo AM, Lacy A, McMahon MJ, Millat B, Schwenk W. The European Association for Endoscopic Surgery clinical practice guideline on the pneumoperitoneum for laparoscopic surgery. Surg Endosc. 2002;16:1121-43.

5- Bisinotto FMB. Endocrine response to cholecystectomy: comparative study between standard surgical management and videolaparoscopy. Braz J Anesthesiol. 1997,8:38-41.
6- Crema E.; Santana JH; Dair E L; Cunha DF; Silva AA. Pulmonar function evaluation pre and postoperatively afther laparoscopic cholecystectomy and subcostal incision. European International Hepato-Pancreato-Biliary Association Congress, Athens, 1995. p. 295-9.

7- Zuckerman RS, Heneghan S. The duration of hemodynamic depression during laparoscopic cholecystectomy. Surg Endosc. 2002;16(8):1233-6.

8- Kolaczkowska E, Seljelid R, Plytycz B. Critical role of mast cells in morphine mediated impairment of zymosan-induced peritonitis in mice. Inflamm Res. 2001;50(8):415-21.

9- Kolaczkowska E, Seljelid R, Plytycz B. Role of mast cells in zymosan-induced peritoneal inflammation in Balb/c and mast cell deficient WBB6F1 mice. J Leukoc Biol. 2001;69:33-42.

10- Barczynski M, Herman RM.A prospective randomized trial on comparison of low-pressure (LP) and standard-pressure (SP) pneumoperitoneum for laparoscopic cholecystectomy. Surg Endosc. 2003;17(4):533-8.

11- Perrakis E, Vezakis A, Velimezis G, Savanis G, Deverakis $\mathrm{S}$, Antoniades J, Sagkana E. Randomized comparison between different insufflation pressures for laparoscopic cholecystectomy. Surg Laparosc Endosc Percutan Tech. 2003;13(4):245-9. 12- Ribeiro RA, Vale ML, Thomazzi SM, Cunha FQ, Ferreira $\mathrm{SH}$. Involvement of resident macrophages and mast cells in the writhing nociceptive response induced by zymosan and acetic acid in mice. Eur J Pharmacol. 2000;387:111-8.

13- Vale ML, Marques JB, Moreira CA, Cunha FQ, Ribeiro RA. Antinociceptive effects of interleukin-4, -10, and -13 on the writhing response in mice and zymosan-induced knee joint incapacitation in rats. J Pharmacol Exp Ther. 2003;304(1):102-8. 14- da Rocha FA, Teixeira MM, Rocha JC, Girão VC, Bezerra MM, Ribeiro R de A, Cunha F de Q. Blockade of leukotriene B4 prevents articular incapacitation in rat zymosan-induced arthritis. Eur J Pharmacol. 2004;16;497(1):81-6.

15-Vale ML, Benevides VM, Sachs D, Brito GA, da Rocha FA, Poole S, Ferreira SH, Cunha FQ, Ribeiro RA. Antihyperalgesic effect of pentoxifylline on experimental inflammatory pain. $\mathrm{Br}$ J Pharmacol. 2004;143(7):833-44.

\section{Correspondence:}

Eduardo Crema

Conflict of interest: none

R. Marcos Lombardi, 305

38050-170 Uberaba - MG Brazil

Phone: (55 34)3318-5288 / 9972-3883

Received: November 06, 2007

cremauftm@mednet.com.br

Review: January 15, 2008

Accepted: February 20, 2008

\section{How to cite this article}

Crema E, Silva BF, Silva PL, Rodrigues Jr V, Cunha F. Innovative technique for the study of pneumoperitoneum in the evaluation of abdominal pain after chemical irritation with zymozan. Acta Cir Bras. [serial on the Internet] 2008 May-June;23(3). Available from URL: http://www.scielo.br/acb

*Color figures available from www.scielo.br/acb 